\title{
Radical Skin, Moderate Masks: De-radicalising the Muslim and Racism in Post-racial Societies
}

\author{
Yassir Morsi \\ London: Rowman \& Littlefield, 2017. 186 pages.
}

The tone of this book is set on its first page. As the second plane collided with the World Trade Center on September 11, 2001, Yassir Morsi whispered to himself: what have we done? (3). The rest of the book responds to this whisper; it deconstructs the utterance as the scene of a colonial interpellation and tracks out the political permutations available within it. Ultimately Morsi's effort is to de-naturalize (bring into view, render explicit) the powerful, racialized psychodynamics of that moment in which, as he writes, "I knew of a responsible Other."

The structure of this discourse is ruthless. It conscripts Muslims and then compels us to answer to its terms. Its demands are extensive but its imperative is simple: to be a good Muslim. This means performing our civility, optimism, and moderation. It means modulating/buffering the "pain (and words) of colour" (7). Above all it is an aesthetic project that blinds us from/binds us to the violence of white supremacy (its gifts: equality, rights, liberty). And its reach is pervasive (on which more below). That is to say, whether in the historical Muslim heartlands but certainly among younger Muslim communities in/of the West, the culture talk (the culture itself) of 
the War on Terror marks "spatial, moral, and political boundaries" (22) (the psychic geography of Islamophobia) among which we must find place. The first page of this book following the table of contents announces the introductory part 1 . The word "introduction" is struck through and followed by two periods and then, in Arabic script, by the basmala (or at least its incipit). But its words are reversed so that it is written backwards (alläh $b i$-sm). What an odd error, I thought as I turned the page, too bad no editor caught that. I understood it as a typographical mistake because, although Morsi repeatedly refers to this basmala, he does not mention its reversal. Revisiting the introduction after reading the book, though, I understand the syntagm as an expression of the argument: its pain and contortion. Even the ritual supplication initiating an act ("in the name of God") is twisted, its conditions of presentation forcing an appearance according to another syntax. The Muslim is caught by this grammar. There is no private space of faith preserved or protected or immune against it, no retreat to quietism possible that is not also implicated in this compulsive division.

The book comprises fifteen chapters divided equally into five parts including an introduction and conclusion. The three middle parts explore three moderate 'masks' of the Muslim: fabulous (by which Orientalism can be exposed/answered), militant (by which we can claim authentic Islam), and triumphant (by which we finally come to belong in the West, in gratitude). Morsi develops his account of these 'masks' with heuristic reference to the two Nietzschean principles named after Apollo and Dionysis. These give a "vocabulary" (24) to his effort to "write the stifled voice of a Muslim of the West" (12). The Apollonian measure is a rhetoric without remainder, of clean divisions and political resolution (e.g. post-racial society). But Dionysian excess cannot be contained; it is a contaminating barbarism which threatens Apollo's culture (e.g. post-racial society as the new horizon of racism: 132). Morsi describes the civilizing effort targeting the Muslims, dividing good Muslim from bad, as an Apollonian project (one in which Muslims too participate). The Dionysian remainder, by contrast, slips out from behind the mask, irrupting when the latter falters. Yet there is an analytic fold at stake because the very separation of Apollo from (or, what secures Apollo against) Dionysis is an Apollonian cut. Lingering with the Dionysian, that is, deconstructs the logic that divides Apollo from Dionysis. The short sections of each chapter "reorient" the reader through Morsi's own restless return to the slipping of the masks ("the Muslim world is in turmoil and so am I," 5). He continues: "The Dionysian thrown-ness that I will describe and have and inherited as a Muslim of the West deserves 
words beyond those of [this grammar]" (5). This thrown-ness deserves words; Radical Skin, Moderate Masks is an effort to reckon with that need, if not fulfill it. Again, Morsi does not account for these masks in order to strip them away, that is, to recover an authentic Muslim voice outside its racialization/politicization. He does not seek to redeem the present by fully documenting the culture of the War on Terror, as though its influence could be fully accounted for (and so resolved). Morsi describes how he envisioned this book-a critical analysis of how Countering Violent Extremism (CVE) policies racialize Muslim communities-until he realized that such analysis could lend itself (in its style and critical apparatus) to such an Apollonian project (even, for example, facilitating better CVE). Instead the book adopts an autoethnographic mode to simply demonstrate how the very terms we have for articulating Muslim life in the West-the modes of critique (mask 1), authenticity (mask 2), and belonging (mask 3) - are beholden to that same political culture, where the first stage of radicalization routinely assessed by CVE programs (in schools, in hospitals, in prisons) actually lies (in the words of an infamous NYPD report) "prior to exposure to jihadi-Salafist ideology" (17)—in short, comprising all of ordinary Muslim life.

Each part of the book takes up cultural exhibits, texts, and figures of Islam in the West (often Australian but paradigmatic beyond that continent) to explore possibilities of narration and action. The first mask, "Fabulous," is the "reaction formation" (57) of/against Orientalism. This is the work that goes into dispelling stereotypes and showing that Muslims are not what the narrative of the War on Terror says we are. But Morsi shows that this labor only begins "when a Muslim accepts this narrator's call" (38). The invitation to critique these myths is a trap because it requires we accept its vocabulary (for example, that Western Muslims such as Waleed Aly are situated between "Islam and the West," as though our ways of "being Muslim [do not] refract through being Western" with its attendant "power of racism and whiteness," 42-43). This is the mask by which the critic of Orientalism acts as Muslim therapist to soothe white anxieties (Sayyid) (45), distinguishing Western Islam from the brutality of ISIS, for example ("the specular image of my 'inner' moderate who wanted so desperately to explain to the white gaze that we were not terrorists," 49). Although it has more sophisticated formations as well, ultimately its aim is to locate Islam/Muslims in the West ("a representation of our normalcy within the fascinating tales of Orientalism's Islam," 58). 
The second mask, "Militant," names the cathexis of Islam as an idealized escape from the history of colonialism and racialization. The Muslims may be ignorant, wounded, or stupid, trapped by that history, but true Islam is not defined by it. This is traditional Islam as a Third Way (neither communism nor capitalism, right nor left). This gets analytically tricky, however. What is of issue in this mask, I would clarify within the terms of Morsi's argument, is not the effort at reform itself, because of course all Muslim reformers will be marked by the history they struggle against; the inheritance of Islamic traditions of knowledge and practice bears a complex temporality that both receives and resists the present. Instead I would emphasize that the mask of militant moderation refuses to encounter the present except as what requires Apollonian resolution. It relies upon a distinction between real and ideal Islam through which these reformers' projects are structured as a promise (of authenticity), the hinge between real and ideal. This bears careful thinking through, when Western Muslim communities are roiled by their own culture wars and their charismatic authorities are in question. The now-embattled Tariq Ramadan's Western Muslims and the Future of Islam, for example, presents an Islamic solution to social segmentation in Europe and invites Western Muslims to integrate as full citizens and confident Muslims at once. In doing so, Morsi comments, he also consolidates a "post-racial fantasy" (77), "confirm[ing] the liberal faith that we can end racism by adjusting attitudes" (78).

But it is Hamza Yusuf's 2001 essay "A Time for Introspection" which best illustrates what Morsi calls the militant mask. There are two types of extremists in religion, Yusuf explains: reactionaries (who see the world in black and white) and radical extremists (reactionaries who believe the ends justify even violent means). But the true problem lies deeper, he concludes: "We have lost our bearings because we have lost our theology...we have almost no theologians in the entire Muslim world" (cited at 81). True Islam teaches that "Allah is the power behind all power; that it is Allah who subjugates one people to another; that He gives dominion to whom He pleases and that He takes it away from whom He pleases" (cited at 81). Elaborating this metaphysics, reviving this theology of moderation, and rebuilding Muslim literate culture will teach Muslims the truth about their religion (and so will solve the problem of radical extremism). Of course, affirming divine omnipotence resonates with all manner of activist projects, but Yusuf consistently invokes this principle to authorize political quietism (cf. most recently his role at the UAE Forum for Promoting Peace in Muslim Societies). Within the grammar of the War on Terror, Morsi observes, this 
also functions to "pass on the baton of Otherness to even more undesirable and illiberal Muslims" (87); "it once again forecloses the Dionysian as we wax lyrical about some Apollonian and indulgent saintly order stolen from us by the bad radicals" (88). The pursuit of authenticity is the quintessential modern malaise, and is conducted in various idioms; as modernists, such reformers defend true Islam from those they call "extremists" on the one hand and "postmodernists" (and, recently, "feminists") on the other. Claiming this authentic Islam under the heading of tradition ("traditionalists"), they displace the present and its material conditions in the name of classical Islamic theology. In consolidating this (often gendered) hierarchical space of authenticity, however, they simultaneously participate in a decidedly modern division of labor (ideal vs. real, ethics vs. politics, metaphysics vs. society) which abstracts its reliance on racial capitalism. In contrast, Morsi insists, real reform "must account for the overturning of material condition" (88).

Finally, the third mask, "Triumphant," turns to the West as the "true embodiment" of Islam (99). Dionysian Islam endures beneath/against the above efforts to smooth it away and is finally confronted as something we cannot reconcile. Emblematic of this mask is Maajid Nawaz, the ex-Islamist whose conversion to liberalism famously led him to found the counter-extremism think tank Quilliam. This mask is less interested in answering Orientalism and relinquishes the project to instantiate a pristine past. Rather than contesting or disavowing the present, it rationalizes it. The triumphant moderate overidentifies with the white colonial world. This process, much like the first two masks, makes the violence of racism incidental to the West. The relation between Apollonian and Dionysian Islam, however troubled it was in/by the first two masks, is here severed altogether: "the Other without his or her Otherness" (116).

The dialectical relationship between the three masks deserves comment. These modes of moderation-fabulous, militant, triumphant-are not simply three interchangeable positions available to the Muslim within the culture talk of the War on Terror. They are also dramatic "acts" which build upon one another. Thus the militant moderate discovers authenticity as a way of substantiating the fabulous moderate's critique, while the triumphant moderate belongs in the West perhaps because the effort to recuperate authentic Islam collapsed. In part we glean this succession because of how it is narrated in the book, as Morsi's own journey of reading and rereading Said's Orientalism. This makes the genre of Radical Skin, Moderate Masks a Bildungsroman of sorts, though its mood is ironic. Morsi 
looks back across what he has written to find that Fanon completes Said: although "Said spoke as an exile in America, Fanon spoke as an exile to himself" (124). Hence the latter's importance: within the culture of the War on Terror, Morsi repeats,

My Islam is always corrupted. I have never known a neutral ground. I have never breathed in a language not racist. For a traumatic affect comes with the Muslim's interpellation into the War on Terror. (...) The ambivalent relation I have with the 'radical' thus grows and so does my will to exterminate the brute. (129-130)

These three masks come with a further cost. Performing the moderate, whether fabulous, militant, or triumphant, simply fails to deliver the recognition it promised. "It simply keeps us sealed within its web of language and gaze" (131). Morsi has learned this failure and this trap; as a work of care for the Muslims of the West (many of us have also traveled this journey), Radical Skin, Moderate Masks exemplifies his search for a voice beyond the compulsive performance of moderation.

It remains only to register a certain reservation about the way in which Fanon's Black Skin, White Masks is mimicked/echoed by this book (not least in its title). Early on, Morsi describes reading Fanon as what collapsed his subjectivity. Reading Fanon showed him the colonial "crudity" and "inanity" (Nandy) of the beguiling and heroic collocation he once relied upon-"to find myself a subjectivity, to fight racism, to be Muslim" (4) — because this robust discovery of a critical Muslim subjectivity still courses with the desire for white recognition. This is not a simple homage ("I owe Fanon almost everything," 9), for Morsi acknowledges the hiatus between Fanon's blackness and his own being-Muslim. To be clear: even though the title invites such a reading, Morsi is not substituting his "Muslim" for Fanon's "black". That would abstract the specificity of blackness from the history of racialization by rendering Europe's others symmetrical/substitutable within that history; it would dematerialize the role of antiblackness within that history by making blackness one "subjectivity" among others. Even so, Morsi continues, Fanon does teach how the humiliating Muslim endless pursuit of recognition is also bound indelibly to the anxious white gaze.

Of course Islam is not a race, Morsi preempts critics-but then racism has never been about the racialized body alone so much as the division of body from culture, flesh from spirit. (Christianity was already there organizing the European invention of race.) Instead of analogizing "blacks" to 
"Muslims" and "whites" to "moderates", that is, or (in what amounts to the same thing) suggesting that Islam is originally/properly theological only to be later/improperly racialized, Morsi begins and ends with the fact of racism as a structuring force, a fact whose psychodynamics Fanon teaches. The continuing conversation to be had, then, does not lie in debating how appropriate 'critical race theory' is for addressing Islam-a subterfuge that bespeaks the dream for an Islam immune from the history of racialization, a dream Morsi might call Apollonian, when that history already conditions (if not structures) the terms of our loss and our inheritance, our practice and concepts. Instead Morsi suggests we might follow Fanon's path through another violence, an antagonism to the colonial world that begins always with "the radical act of peeling off the white gaze that laces the body of colour and its psychic register" (130). In the final line of the book, Morsi asks if "the Muslim" (not individual Muslims, of course, not any particular Muslims, but this figure) can exist outside the War on Terror. This is a bracing question because it gauges the difficulty ahead. But there is a relief in it as well, one registered in 'Ali Shari'ati's translation of Fanon's The Damned of the Earth: "Come, comrades! The story of Europe has forever come to an end. We must find a different story."

Basit Kareem Iqbal $\mathrm{PhD}$ candidate, Department of Anthropology and Program in Critical Theory University of California, Berkeley 